\title{
Characterization of dietary fiber and pectin of cassava bread obtained from different regions of Venezuela
}

\section{Caracterización del contenido de fibra dietaria y pectina de casabe obtenido de diferentes regiones de Venezuela}

Benito Infante R. (1)

Omar García O. (1)

Carlos Rivera (2)

\begin{abstract}
Three varieties of cassava bread were analyzed by proximal analysis and biochemical methods. The content of protein, fat, carbohydrate, ash, crude fiber and dietary fiber (DF) differed significantly between each sample $(p<0.05)$. The cassava variety "Puerto Ayacucho" showed a higher content of insoluble DF (4.7\%), soluble DF (1.6\%), total DF (6.3\%) and pectin $(0.61 \%)$ ) in comparison with the varieties of "Rio Chico" and "Caripito". Soluble DF retains significant amounts of water in the digestive tract, and this fact, combined with its reported effect of lowering human serum cholesterol its low moisture plus a high carbohydrate content confirm the suitability of this bread as an important nutritional food.

Key words: cassava bread, pectin, total dietary fiber, soluble dietary fiber.
\end{abstract}

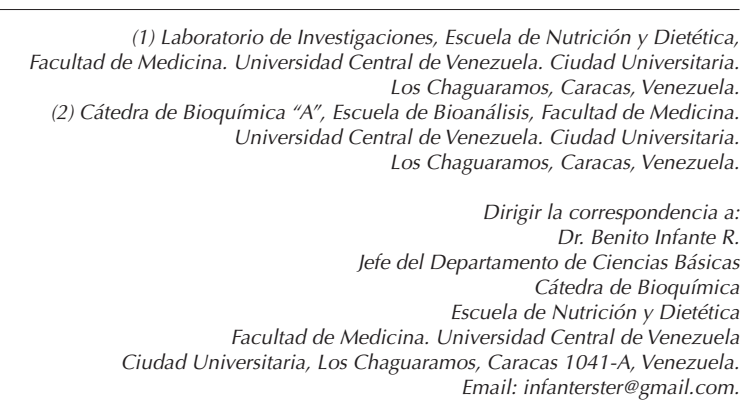

Este trabajo fue recibido el 5 de Septiembre de 2012 y aceptado para ser publicado el 4 de Mayo de 2013.

\section{INTRODUCTION}

Cassava is one of the few root crops known and is an important food source in many countries of Africa, Latin America and in some Asian countries. In Venezuela, for instance, the root is eaten in a number of ways such as in soups, as casabe (cassava flat cake), as naiboa (cassava with raw sugar and grated white cheese formed into a flat cake) and as buñuelos (fried cassava dough balls with cane-juice syrup). Cassava contains significant amount of iron, phosphorus, calcium, and is relatively rich in vitamin C (1). Soluble fiber accounted for nearly 40 percent of the total dietary fiber content of cassava bread. The soluble fraction consists mainly of uronic acids and glucose polymers (pectins and beta- glucans), whereas the insoluble fraction is rich in cellulose and lignin. There is an increasing drive to include food rich in fiber in the daily diet, and on those grounds cassava could be a good source of dietary fiber (2).

An adequate intake of dietary fiber in the daily diet was promoted a long time ago as a consequence of observed beneficial effects in humans (3-5). Recent investigations have demonstrated that a high fiber diet could prevent or alleviate maladies such as cardiovascular diseases, diabetes, diverticu- litis and colon cancer (6-9). Therefore, more raw fiber is being incorporated into food.

Cassava could be a good source of dietary fiber. Cassava (Manihot spp) is a widely cultivated staple crop in tropical countries, including Venezuela. Cassava bread has a long historical tradition, extending over many centuries, among the indigenous residents of Venezuela, and it has played vital roles in the diets of many indigenous tribes in Venezuela as a major source of carbohydrate (10).

Sweet cassava is widely used and requires no special detoxification process; it can be eaten raw, sun-dried, kilndried, or cooked. For bitter forms, a common method of fixing peeled cassava is boiling pieces of the root for a long time, which drives off the poison as a gas (HCN). Some African and Amazonian cultures express the poison by squeezing the roots in a "tipitipi" or by pressing and pounding grated root with heavy stones or logs. Soaking roots is another technique.

In Venezuela, some research has been done on the nutritional value and content of dietary fiber, resistant starches and other substances in cassava bread (11,2,12-14). The present study was undertaken to characterize the dietary fiber and 
pectin content of cassava bread collected from three processing locations in Venezuela.

\section{MATERIALS AND METHODS}

Proximal analysis

In summary elaboration of "casabe" is as follow: After harvesting, roots from cassava (Manihot esculenta Granz) were peeled, soaked and grated, squeezed, sifted and the glucocianogens lixiviate with by using a press. Then passed through a sieve to obtain fine flour and placed on a hot plate to form a layer approximately 5 millimeters in thickness in the form of flat cake and cooking until flour begins to harden. Finally, cakes are exposed to the sunlight. The cassava breads used in this study were collected by buying from supplier beside the main road, three times per year in three different locations of Venezuela: "Caripito" Monagas state; "Rio Chico" Miranda state and "Puerto Ayacucho" Amazonas state. Each stock sample $(n=5)$ was dried in an oven vacuum $\left(55^{\circ} \mathrm{C}\right)$ until reaching a constant weight at $50 \pm 5^{\circ} \mathrm{C}$, milled to a particle size less than $0.4 \mathrm{~mm}$ in a Cyclone mill (Tecator, Sweden) and packed in special polythene bags and analyzed for: moisture, crude protein $(\mathrm{N} \times 6.25)$, carbohydrate, ash, fat and crude fiber according to the AOAC procedures (15).

\section{Determination of dietary fiber}

Total dietary fiber (TDF) and insoluble dietary fiber content (IDF) was determined by an enzyme-gravimetric method described by Prosky et al. (16). Briefly, 0,5 g of sample was digested with thermostable $\alpha$-amylase (Sigma) at $\mathrm{pH} 6.0$ for 30 min at $100{ }^{\circ} \mathrm{C}$ and allowing to cool, then $\mathrm{pH}$ was adjusted to 7.5 and incubated with protease VIII (Sigma) for 30 min at 60 ${ }^{\circ} \mathrm{C}$. After cooling the sample was adjusted to $\mathrm{pH} 4.5$ and incubated with amyloglucosidase at $60^{\circ} \mathrm{C}$ for $30 \mathrm{~min}$. The sample was precipitated and preweighed crucibles containing celite (Sigma Chemical Co.) were used to filter the phase digested by the above enzymes. The residue was washed with ethanol and acetone. Determination of protein and ash was as described by Prosky et al (16) and the AOAC gravimetric method nº 955.29 (15). SDF was determined in the combined filtrate and washing solution from the IDF procedure as described above. TDF was assumed as the sum of IDF+SDF fractions.

\section{Pectin extraction and determination}

$2 \mathrm{~g}$ of duplicate cassava samples prepared as above were rinsed with neutral ethanol (80\%) then dried at $50-55^{\circ} \mathrm{C}$ and the pectin was extracted with a boiling solution of $0,25 \%$ oxalic acid and 0,25\% ammonium oxalate and filtered. The filtered extract was centrifuged for $750 \times \mathrm{g}$ for 15 minutes (17). The pellet was suspended in $0,5 \mathrm{~N} \mathrm{NaOH}$. To the latter suspension was applied the pectin determination using the carbazol reaction of Dische (18), modified by Bitter et al (19) and Mc Cready (20).

\section{Statistical analysis}

Means were compared by Student's t-test, using the Minitab, statistical software, version 13.20 (USA).

\section{RESULTS}

Proximal analysis of cassava samples

Results are shown in table 1. Protein, fat, carbohydrates, ash and crude fiber as components of the cassava differs significantly $(p<0.05)$ between each sample, which suggests differences between varieties of cassava plants used or the effect of soil on the plant. We have at present no botanical evidence to allow us to support one or more of these propositions.

The moisture for the cassava samples (table 1) ranged between 9.6 and $10.4 \%$ and the proteins between 1.1 and $1.3 \%$. Although the fat fraction was below one percent, it showed a small range between 0.4 and 0.6 percent. The other components were, Ash between 1.4 and 1.7\%, total carbohydrates between 86.9 and $87.3 \%$, and crude fiber between 1.7 and $1.9 \%$.

Comparison of pectin and dietary fiber among these three varieties of cassava is shown in table 2 . The results indicated significant differences $(P<0.05)$ for each variable when compared among different samples. The composition of pectin was higher for the cassava "Puerto Ayacucho" while, the pectin content was lower for cassava "Caripito" and "Rio Chico". The total dietary fiber, ranged between 5.2\% and 6.3\%, and the insoluble dietary fiber content was similar for all three samples, averaging $4.6 \%$. While the soluble fraction of dietary fiber showed a range between 0.7 and 1.6 percent, being the highest value of SDF for the cassava "Puerto Ayacucho".

\section{DISCUSSION}

The edaphological conditions for the culture of Manihot esculenta Granz are not the same in the regions where the samples of cassava bread were obtained for this study. The samples of cassava bread were obtained from three different locations of Venezuela and it is possible that the observed differences for each analyzed variable between different cassava breads could be due to the variety of cassava plant, or the soil, according to the geographical location, or may be due to variations in the traditional methods of production. In the next study will be analyzed the different methods of production of cassava bread.

These results are of great interest to improve the data about the content of nutrients in Latin-American foods.

\section{TABLE 1}

Proximal analysis of cassava bread in three different places of Venezuela (g/100g of food).

\begin{tabular}{|c|c|c|c|c|c|c|}
\hline Locations & Moisture & Protein & Fat & Carbohydrates* & Ash & $C F^{*}$ \\
\hline Caripito & $10.4 \pm 0.02 a$ & $1.3 \pm 0.08 a$ & $0.4 \pm 0.08 a$ & $86.9 \pm 0.86 a$ & $1.4 \pm 0.12 a$ & $1.8 \pm 0.22 \mathrm{a}$ \\
\hline Rió Chico & $9.9 \pm 0.12 b$ & $1.1 \pm 0.17 b$ & $0.5 \pm 0.12 b$ & $87.2 \pm 0.41 b$ & $1.5 \pm 0.12 b$ & $1.9 \pm 0.08 b$ \\
\hline Puerto Ayacucho & $9.6 \pm 0.12 c$ & $1.2 \pm 0.14 c$ & $0.6 \pm 0.21 c$ & $87.3 \pm 0.29 c$ & $1.7 \pm 0.21 c$ & $1.7 \pm 0.09 c$ \\
\hline
\end{tabular}

Values are means of al least 4 independent determinations \pm standard deviation.

${ }^{*}$ CF: Crude fiber.

*The carbohydrates were obtained by difference.

Means on the same column with different superscript are significantly $(P<0.05)$ different. 
The finding from this study, that all three samples of cassava bread have a high total dietary fiber (TDF) content averaging $5.6 \%$, is very important bearing in mind the poor DF consumption in most populations around the world. The higher content of DF (6.3\%) in the cassava cake of "Puerto Ayacucho" is possibly associated with their traditional production, duration of cooking and drying time. This result suggests the consumption of cassava bread by urban and rural locations, as well as in locations exclusively inhabited for indigenous tribes in Venezuela, is very important for their health status.

In the table of composition of Venezuela foods, values of total dietary fiber were reported as $4.1 \%$ for cassava cake, without specifying variety or geographical region from where the samples was produced, and was bellow the value shown in table 2 (1).

Earlier studies carried out on cassava bread in Venezuela by other researchers shown values of insoluble dietary fiber of $5.6 \%$ and soluble dietary fiber of $3.8 \%$ in cassava cakes bought in the city of Caracas, "Distrito Capital." Schnell et al (14), which were higher values for each fiber fraction than the values reported in the present work. On the other hand, Sangroni et al (13) reported for this kind of food values of 4.09\% total dietary fiber; $3.39 \%$ insoluble dietary fiber and $0.7 \%$ soluble dietary fiber which were smaller values than those reported here. Also, the investigators of the above work did not specify the location where the cassava cake was bought. The latter makes difficult any comparison of such studies with this one.

Chonchol et al (11), analyzed cassava bread samples from different regions of Venezuela, finding for insoluble dietary fiber a range of 4.92-5.67\% and soluble dietary fiber range $3.40-3.78 \%$ on a dry basis. Their values of insoluble fiber were very similar to those shown in this article; nonetheless their soluble fraction was higher than the values reported in table 2 . It is important to point out that the reported values by Chonchol et al (11) were in dry base and in the present study was in wet base as described by most of the international papers.

Tovar et al (2) carried out a biochemical analysis of some cassava bread samples from regions of Venezuela, different from the sources described in this manuscript. They reported close to $40 \%$ of SDF of the TDF content in cassava bread. SDF consisted of uronic acids and pectins and beta-glucans, whereas the insoluble fraction was rich in cellulose and lignin. These values for the SDF fraction were higher than figures shown in this manuscript. It is proposed that the difference could be due mainly to the method of Asp et al (21) used by Tovar et al (2) which is an enzymatic-gravimetric method known to retain starch in the dietary fiber fractions.

African investigators carried out a study for evaluation of moisture, total cyanide and fiber contents of "garri" product derived from cassava varieties (Manihot utilissima) obtained from Awassa in southern Ethiopia (22). After various processing operations which involve peeling, washing, grating, fermentation, drying/dewatering, milling/pulverizing and frying/ roasting, the hydrogen cyanide content was reduced. The "garri" is fried and consumed in Central Africa. Unfortunately, the fiber content determination was realized by acid digestion as percentage of dry matter (\% DM) with a result of $1.76 \%$ a value similar to shown in table 1 of this paper, defined as crude fiber and the latter is no longer comparable to DF.

Pectin content in the samples of cassava bread

The cassava bread samples from the Venezuelan Amazon region, (Puerto Ayacucho), yielded the highest values of pectin content, $0.61 \%$, and although it forms a smaller contribution in the total composition of FD, pectin is part of the soluble FD. An earlier paper reported $1.17 \%$ pectin for cassava (dry samples) from "Rio Chico" using the same methodology as described here, and probably the difference from our result obtained for the same source $(0,31 \%)$ could be that here pectin was measured on a wet basis (12).

In general, the pectin content was much smaller than reported values for vegetables and fruit, especially citrus fruits. The average consumption of cassava roots and their derivatives such as "mañoco", "yucuta" and cassava bread are around an average of $300 \mathrm{~g}$ per person/day in the Venezuelan Amazon indigenous tribes(23). Pectin (SDF) would contribute to the diet of Indian communities nearly $2 \mathrm{~g}$ /person/day, which may be increased by additional intake of pectin in fruits and other vegetables. Consequently, it would have a beneficial effect on health. As has been described elsewhere, the metabolic effects of SDF due to colonic fermentation are beneficial (24$28,10)$. Cassava bread provides a good source of calories in the diet, coming almost exclusively from the carbohydrate content ( $87.1 \%$ average), since the lipids and the proteins content represent less than $1.5 \%$ (table 1 ). These results are very interesting. It will be necessary to carry out further studies to determine whether the locations where the cassava bread is made influences the dietary fiber content; including the type of soil (29).

\section{CONCLUSIONS}

The chemical proximal analysis of each sample of cassava bread from three locations of Venezuela, showed very similar values in relation to the content of nutrients. However, there

\section{TABLE 2}

Dietary Fiber and pectin contents in cassava bread in diverses locations in Venezuela ( $\mathrm{g} / 100 \mathrm{~g}$ of food).

\begin{tabular}{|c|c|c|c|c|}
\hline Locations & $\begin{array}{c}\text { Insoluble } \\
\text { dietary fiber }\end{array}$ & $\begin{array}{c}\text { Soluble } \\
\text { dietary fiber }\end{array}$ & $\begin{array}{c}\text { Total* } \\
\text { dietary fiber }\end{array}$ & Pectin \\
\hline Caripito & $4.6 \pm 0.08 a$ & $0.8 \pm 0.08 a$ & 5.4 & $0.34 \pm 0.08 a$ \\
\hline Rio Chico & $4.5 \pm 0.22 b$ & $0.7 \pm 0.12 b$ & 5.2 & $0.31 \pm 0.08 b$ \\
\hline Puerto Ayacucho & $4.7 \pm 0.12 c$ & $1.6 \pm 0.17 c$ & 6.3 & $0.61 \pm 0.07 c$ \\
\hline
\end{tabular}


was a trend for "Puerto Ayacucho" cassava to increase the concentration of nutrients. Perhaps such differences may be due to the crops and production of the cassava bread.

The cassava bread coming from the location of "Puerto Ayacucho" showed the biggest value of TDF. The higher content of TDF may be due to the varieties of cropped Manihot Spp in the Amazonian region of Venezuela .Therefore, considering its important part in the diet and the addition of TDF from other autochthonous foods consumed in Venezuela, it would increase the total consumed DF for those populations.

The results of this work allows us to recommend the consumption of cassava bread in the daily diet, since the FD and pectin content would contribute to the benefit of consumer health in Latin America or elsewhere. It will be necessary to continue evaluation of cassava from other regions in terms of nutrient and DF content and to introduce physiological studies for its complementation.

\section{RESUMEN}

Tres variedades de casabe de yuca fueron analizados mediante el análisis proximal y métodos bioquímicos. El contenido de proteínas, grasas, hidratos de carbono, ceniza, fibra cruda y fibra dietética (FD) difieren significativamente entre cada muestra ( $p<0,05)$. La variedad de casabe "Puerto Ayacucho" mostró un mayor contenido de FD insoluble $(4,7 \%)$, FD soluble $(1,6 \%)$, FD total $(6,3 \%)$ y pectina $(0,61 \%))$ en comparación con las variedades de "Rió Chico" y "Caripito ". FD soluble retiene grandes cantidades de agua en el tracto digestivo, $\mathrm{y}$ este hecho, combinado con su efecto ya reportado de bajar el colesterol del suero humano, así como el casabe de contener un bajo contenido de humedad aunado a un alto contenido de hidratos de carbono; confirma la idoneidad del mismo, como un importante alimento nutricional.

Palabras clave: casaba; pectina; fibra dietética total; fibra dietética soluble.

Acknowledgments: This work was supported by $\mathrm{CDCH}-$ UCV: PI 09-13-5500-2004. Also to Dr. Peter McNaughton of the University of Cambridge for reading this manuscript.

\section{REFERENCES}

1. Instituto Nacional de Nutrición (INN). Tabla de composición de alimentos para uso practico. Publicación $N^{\circ} 52$. Serie de cuadernos azules. Caracas, Venezuela. 2000; p. 64.

2. Tovar J. Bjorck IM. Asp NG. On the nutritional properties of starch and dietary fiber in cassava bread. Nutr Reports Internat. 1989, 39(6):1237-46.

3. Cumming JH. Englyst HN. What is dietary fiber? Trends Food Sci Tech. 1991; 2: 99 - 103.

4. Dukehart MR. Dutta SK. Vaeth J. Dietary fiber supplementation: effect on exocrine pancreatic secretion in man. Am J Clin Nutr. 1989, 50(5):1023-28.

5. Jenkins DJ. Leeds AR. Gassull MA. Cochet B. Alberti GM. Decrease in postprandial insulin and glucose concentrations by guar and pectin. Ann Intern Med. 1977; 86(1):20-3.

6. Lairon D. Arnault N. Bertrais S. Planells R. Clero E. Hercberg S. Boutron-Ruault MC. Dietary fiber intake and risk factors for cardiovascular disease in French adults. Am J Clin Nutr. 2005; 82(6):1185-94.

7. Kaline K. Bornstein SR. Bergmann A. Hauner H. Schwarz $H$. The importance and effect of dietary fiber in diabetes prevention with particular consideration of whole grain products. Horm Metab Res. 2007; 38(9): 687 - 93.

8. Camparato G. Pilotto A. Franze A. Franceschi M. Di Mario
F. Diverticular diesease in the elderly. Digestive Dis. 2007; 25(2):151-9.

9. Queenan KM. Stewart M. Smith KN. Thomas W. Fulcher RG. Slavin JL. Concentrated oat beta-g/ucam, a fermentable fiber, lowers serum cholesterol in hypercholesterolemic adults in a randomized controlled trial. Nutr J. 2007; 6:6 doi:10.1186/1475-2891-6-6 http://www.nutritionj. com/content/6/1/6

10. García OE. Infante RB. La fibra alimentaria y sus aspectos nutricionales. Una visión de los alimentos venezolanos. Informe Médico. 2007, 9(6): 285 - 94.

11. Chonchol N. Tovar J. Dietary fiber content and starch digestibility in cassava bread. Nutr Reports Intern.1988; 38(2):437- 43

12. Rivera CJ. Gerardi AE. Infante RB. Carrasco HJ. Rodriguez $O$. Dietary fiber analysis of cassava using gravimetric methods. Arch Lat Nutr. 1993; 43(1): 73 - 4.

13. Sangroni E. Rebolledo MA. Fibra dietética soluble, insoluble $y$ total en cereales, productos derivados de su procesamiento $y$ en productos comerciales a base de cereales. Arch Lat Nutr. 1993; 43(3): $258-63$.

14. Schnell M. Carvajal ME. Anchustequi B. Effect of cassava bread supplementation on energy intake of rats. Arch Lat Nutr. 1993;43(3):217 - 20.

15. AOAC. Official Methods of Analysis, (1990). 15th edition, AOAC Inc, Arlington, VA, USA.

16. Prosky L. Asp NG. Schweiser TF. DeVries JW. Furda I. Determination of insoluble, soluble and total dietary fiber in food and food products: Interlaboratory study. J Assoc Off Anal Chem. 1988; 71(5): 1017-23.

17. Sabir MA. Sosulski FW. Campbell SJ. Polymetaphosphate and oxalate extraction of sunflower pectins. I Agric Food Chem. 1976; 24(2): 348-50.

18. Dische Z. Color reactions of carbohydrates. In: Whistler $R$, Wolfrom $M$, eds. Methods in carbohydrate chemistry. Vol I. Academic Press, New York, USA. 1962; p. 477 - 512.

19. Bitter T. Muir HA. A modified uronic acid carbazole reaction. Analytical Biochem 1962. 34: 330 - 4.

20. McCready RM. McComb EA. Extraction and determination of total pectic materials in fruits. Anal Chem. 1952; 24: 1986-952.

21. Asp NG. Johansson CG. Hallmer H. Siljestrom M. Rapid enzymatic assay of insoluble and soluble dietary fiber. J Agric Food Chem. 1983; 31(3): 476-82.

22. Enidiok SE, Attah LE, Otuechere CA. Evaluation of moisture, total cyanide and fiber from Awassa in Southern Ethiopia contents of Garri produced from cassava (Manihot utilissima) varieties obtained. Pakistan J Nutr. 2008, 7(5): 625-9.

23. Chacón F. Herrera J. León K. Maldonado M. Vanegas J. Universidad Central de Venezuela. Facultad de Medicina. Escuela de Nutrición y Dietética. Departamento de Ciencias de la Salud Pública. Cátedra de Practicas de Nutrición Comunitaria. Aproximación diagnostica del Estado Amazonas. Tomo I. (Abril 2001).

24. Devin JR. DeMeo MT. Keshavarzian A. Hamaker BR. Influence of dietary fiber on inflammatory bowel disease and colon cancer: importance of fermentation pattern. Nutr Rev. 2007; 65(2): 51 - 62.

25. Tungland BC. Meyer D. Nondigestible oligo and polysaccharides (dietary fibre): their physiology and role in human health and food. Comprehensive Rev Food Sci Food Safety. 2002; 3:73-92.

26. Kim M. Atallah MT. Amarasiriwardena C. Barnes R. Pectin 
with low molecular weight and high degree of esterification increases absorption of $58 \mathrm{Fe}$ in growing rats. J Nutr. 1996;126 (7):1883-90.

27. Baig MM. Burgin CW. Cerda JJ. Effect of dietary pectin on iron absorption and turnover in the rat. J Nutr. 1983; 113(12): 2385-89.

28. Marounek M. Volek Z. Synytsya A. Copikova J. Effect of pectin and amidated pectin on cholesterol homeostasis and cecal metabolism in rats fed a high cholesterol diet. Physiol Res. 2007; 56: 433 - 42.

29. CIAT (International Center for Tropical Agriculture) 2007. CIAT Cassava: A crop for hard times and modern times. In focus crop commitments at www.ciat.cgior.org Accessed October 2007. 